ELORE (ISSN 1456-3010), vol. 17 - 1/2010.

Julkaisija: Suomen Kansantietouden Tutkijain Seura ry.

[http://www.elore.fi/arkisto/1_10/ajankoht_makkonen_1_10.pdf]

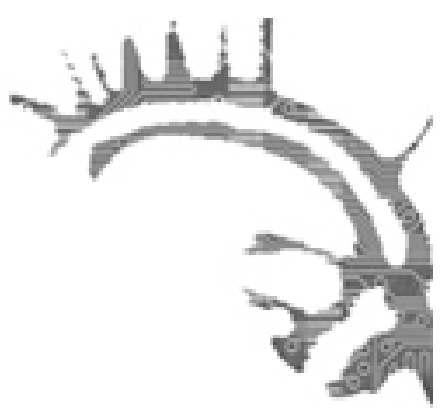

Ajankohtaista

\title{
TuTKIJAN ROOLI MUISTITIETOETNOGRAFIASSA
}

Lectio praecursoria Itä-Suomen yliopistossa 23.1.2010

\section{Elina Makkonen}

Muistitietotutkimus on viimeisten kahdenkymmenen vuoden aikana vakiinnuttanut asemansa suomalaisessa perinteentutkimuksessa ja sen lähialoilla samoin kuin historiantutkimuksessa. Muistitietotutkijat nojautuvat tutkimuksissaan omien alojensa teoreettisiin keskusteluihin, eikä voida puhua yhtenäisestä muistitietotutkimuksen metodologiasta. Muistitietoa sen sijaan lähestytään monista eri näkökulmista tutkimuskysymyksistä riippuen. Tutkimusten aineistoina käytetään sekä haastatteluaineistoja että kirjallisia muisteluaineistoja. Näiden aineistojen tuottamiskontekstit ovat erilaiset, ja niitä myös analysoidaan erilaisin menetelmin. Myös muistitietoon suhtautuminen tietona ja lähdeaineistona vaihtelee.

Muistitietotutkimusta on jaettu tietoteoreettisin, osittain ontologisin perustein, positivistiseen tietoteoriaan ankkuroituvaan selittävään suuntaukseen, hermeneuttiseen tutkimustraditioon pohjautuvaan ymmärtävään ja tulkinnalliseen suuntaukseen sekä kriittiseen muistitietotutkimukseen. Selittäväksi tai realistiseksi muistitietotutkimukseksi nimetyssä lähestymistavassa pyritään selittämään tai esittämään erilaisia menneisyyden ilmiöitä. Muistitieto on tutkimusta täydentävä ja elävöittävä lähde ja tavoitteena on tutkia, mitä on tapahtunut tai miten asiat ovat olleet. Tutkija on lähestymistavassa tarkkailija. Tutkimuksen kohdetta ja aineistoja tarkastellaan ulkopuolisen näkökulmasta, mahdollisimman objektiivisesti. (Ukkonen 2006, 187-189; ks. myös Fingerroos \& Haanpää 2006, 36-40.)

Ymmärtävässä (tulkinnallisessa) muistitietotutkimuksessa, jonka piiriin tutkimukseni lukeutuu, etsitään menneisyydestä faktojen sijaan merkityksiä. Siinä ei pyritä menneisyyden aukottomaan selittämiseen, vaan tavoitteena on menneisyyttä käsittelevän muistitiedon tulkinta ja menneisyyden merkityksen ymmärrettäväksi tekeminen. Muistelussa korostuvat muistelijoiden omat tulkinnat siitä, mitkä asiat ja tapahtumat ovat muistamisen, kertomisen ja säilyttämisen arvoisia. Muistelu nähdään kerrontana, 
menneisyyden tulkintana ja prosessina, ja tiedon tuottaminen vuorovaikutteisena. Niin muisteluprosessi kuin tutkimuksen lopputuloskin ovat luonteeltaan konstruoituja, ja tutkija on osa tulkintojen tuottamisen prosessia. Ymmärtävässä muistitietotutkimuksessa tutkimustulos on yleensä subjektiivinen ja monimerkityksinen neuvottelutulos tai tulkinta. Kriittinen muistitietotutkimus taas pyrkii menneisyyden tulkintaan kriittisesti ja emansipatorisesti. (Ks. esim. Fingerroos \& Haanpää 2006, 36-40; Haanpää 2008, 49; Ukkonen 2006, 187-189.)

Muistitietotutkimuksen ohella hyödynnän tutkimuksessani etnografisen tutkimuksen antia. Etnografia on alunperin antropologian piiristä noussut lähestymistapa, mutta sittemmin etnografinen metodologia on levinnyt laajemmalle. Klassiset etnografiat eli tutkittavan kansan, kulttuurin tai yhteisön kuvaukset ovat perustuneet pitkäkestoiseen kenttätyöhön. Antropologit ovat eläneet tutkittaviensa keskuudessa ja pyrkineet opettelemaan heidän kielensä ja kulttuuriset tapansa sekä myöhemmin kirjoittamaan tutkittavasta kohteesta mahdollisimman kattavan kuvauksen. Nykyisin etnografista tutkimusta tehdään usein tutuissa kulttuureissa ja yhteisöissä. Etnografisen tutkimuksen ytimessä on edelleen tutkijan osallisuus sekä ruumiillinen ja emotionaalinen läsnäolo. Etnografi tutustuukin itse tutkimuskohteeseensa ja opettelee toimimaan sen arkisissa, sosiaalisissa ja kulttuurisissa järjestyksissä. Hän suodattaa omia kenttäkokemuksiaan, paikantaa niitä analyyttisesti ja tuo tulkitessaan esille oman toimintansa. (Lappalainen 2007, 10.)

Etnografisuus tarkoittaa tutkimuksessani pitkäkestoista kentän eli tutkimieni yhteisöjen ja ryhmien tuntemusta, haastatteluiden tekemistä ja aineiston analysointia laadullisin menetelmin sekä refleksiivistä otetta tutkimuskohteen kuvailussa ja tutkimuksen kirjoittamisessa. Refleksiivisen ihanteen mukaisesti tutkijan pitäisi tutkimusprossinsa eri vaiheissa, niin kentällä kuin tutkimusta kirjoittaessa, tiedostaa omat henkilökohtaiset sitoumuksensa, menetelmänsä, teoriansa ja käsitteensä. Samoin hänen pitäisi hahmottaa ja kirjoittaa auki, millainen tutkimuksen tietoteoria ja intressit tutkimuksentekoa ohjaavat. Refleksiivisyys ei tarkoita pelkästään itsereflektiota ja itsensä kirjoittamista tekstiin, vaan yleensäkin koko tutkimukseen kohdistuvaa paikantavaa katsetta, tulkintoja ohjaavien seikkojen tiedostamista ja tutkimusprosessin auki kirjoittamista. Tutkijan pitää siis ymmärtää yhteytensä tutkimuskohteeseen ja hahmottaa ne kehykset, joista käsin ilmiötä tarkastelee. (Ks. esim. Fingerroos 2003; Ojanen 2008.)

\section{TUTKIMUKSEN MUISTITIETOHANKKEET}

Väitöskirjani Muistitiedon etnografiaa tuottamassa on refleksiivinen tutkimus kolmesta Pohjois-Karjalaan paikantuvasta muistitietohankkeesta. Olen itse ollut mukana hankkeissa tutkimuksen tekijänä, julkaisun kirjoittajana ja perinnepiirin ohjaajana. Hankkeissa näkyvät ryhmän ja yhteisön oman historian rakentumisen prosessit mutta myös tutkijoiden asema ja merkitys yhteisöjen historiakuvien ja niitä koskevan etnografisen tiedon tuottamisessa.

Kaltimon tehdaslapsuutta käsittelevän tutkimukseni taustalla on 1980-luvulla Enossa toiminut tehdasperinnepiiri, johon osallistui noin kymmenen entistä Kaltimon 


\section{Elina Makkonen: Tutkijan rooli muistitietoetnografiassa}

pahvitehtaalaista. Perinnepiirin toiminnan yhtenä lähtökohtana on ollut entisten tehtaalaisten kiinnostus menneisyyttään kohtaan. Kiinnostus muistelemiseen lähti liikkeelle entisten pahvitehtaalaisten keskuudesta, mutta kansalaisopiston ja kulttuuritoimen tultua mukaan syntyi perinnepiiri ja alkoi systemaattinen aineiston kokoaminen.

Tehdasperinnepiirissä muisteltiin ja tutkittiin tehtaalaisten työtä ja elämää vuosina 1897-1953 toimineen Kaltimon pahvitehtaan yhteisössä. Aineiston pohjalta koottiin Enoon kesäksi 1984 näyttely "Kaltimon pitkä löysi”, joka oli muokattuna esillä myös valtakunnallisilla kotiseutupäivillä Ilomantsissa 1985.1990-luvun alkuvuosina tehtaan maisemiin raivattiin edelleen avoinna oleva Tehdasperinnepolku. Samoihin aikoihin myös paikallinen kotiseutuyhdistys, Eno-Seura, alkoi kiinnostua tehdasperinteestä ja osa perinnepiirissä kootusta aineistosta sijoitettiin Enon kotiseutumuseoon.

Tulin mukaan Kaltimo-projektiin 1990-luvulla. Tein tuolloin Enossa tehdaslapsuutta käsitteleviä haastatteluja, joiden pohjalta olen kirjoittanut kaksi opinnäytettä (Makkonen 1993; 2000a), yleistajuisen julkaisun (Makkonen 1997) ja joukon artikkeleita (esim. Makkonen 2000b; 2004b) sekä toteuttanut näyttelyn. Käsittelen kolmessa väitöskirjani artikkelissa Kaltimon tapausta.

Toinen tutkimukseni hanke on Kontiolahdella 1990-luvun loppupuolella toteutettu Kotiseutuna Kontiolahti -kyläkirjahanke, jonka ideoinnissa ja toiminnassa olin mukana. Hankkeessa tallennettiin kylien perinnettä, työstettiin koottuja aineistoja ja tehtiin kyläjulkaisuja, joita tarkastelen yhdessä väitöskirjani artikkelissa. Kyläkirjahankkeen aikana seitsemällä Kontiolahden kylällä toimi perinne- tai historiapiiri. Hankkeen aikana ilmestyi kaiken kaikkiaan kuusi kylälehteä ja kolme kyläkirjaa. Joillakin kylillä toiminta on jatkunut myös hankkeen toiminnan loputtua ja joitakin kyläjulkaisuja on ilmestynyt. Me hankkeen työntekijät taas kirjoitimme perinnepiireistä saatujen kokemustemme pohjalta oppaan kyläkirjan tekijöille (Makkonen et al. 1999).

Sekä Kaltimon pahvitehtaan historian tutkiminen että Kontiolahden kyläkirjahanke asettuvat laajempaan paikallishistoriallisen harrastuneisuuden kenttään. Kaltimon tapaus kytkeytyy, 1980-luvulla syntyneenä hankkeena, selkeästi työväen historian ja perinteen tutkimiseen ja perinnepiiritoimintaan. Kontiolahden kyläkirjahankkeen taustalla taas on kotiseututyö, kylien aktivoiminen kylätoimintaan samoin kuin paikalliskirjallisuusilmiö. Suomessa on ilmestynyt viimeisten parinkymmenen vuoden aikana todella runsaasti kyliä ja kaupunginosia, erilaisia yhteisöjä ja ryhmiä, yhdistyksiä, sukuja ja yksittäisiä henkilöitä koskevia julkaisuja. Tällaisen kirjallisuuden määrää on vaikea kartoittaa, mutta julkaisuja on jo nyt ainakin tuhansia, ja erilaisten paikalliskirjojen tekeminen jatkuu edelleen hyvin vireänä.

Myös tutkimukseni kolmas hanke, Joensuun yliopiston muistitietoprojekti, lähti liikkeelle yhteisön sisältä. Yliopiston täyttäessä 30 vuotta (vuonna 1999) virisi ajatus yliopistoa koskevan muistitiedon kokoamisesta. Tuolloin perustettiin muistitietotoimikunta, jossa oli edustus humanistisesta tiedekunnasta, perinteentutkimuksen, historian ja sosiologian oppiaineista sekä Suomalaisen Kirjallisuuden Seuran Joensuun perinnearkistosta. Työskentelin itse yliopiston muistitietoprojektissa kahteen otteeseen. Koordinoin haastatteluaineiston keruuta ja myöhemmin kirjoitin ja toimitin aineiston pohjalta muistitietojulkaisun Muistin mukaan. Joensuun yliopiston suullinen bistoria (Makkonen 2004a). 


\section{Elina Makkonen: Tutkijan rooli muistitietoetnografiassa}

Yliopiston muistitietoprojektille on vaikea löytää suomalaista esikuvaa. Hanketta voidaankin pitää pioneerihankkeena yliopistojen, mutta myös muiden instituutioiden historiankirjoituksen piirissä. Tähän mennessä muistitietoa tai perinnettä ei ole hyödynnetty yliopistojen historiankirjoituksessa muualla kuin Joensuussa, vaikka yliopistoista on kerätty kaskuja (Hosiaisluoma 2000; Soikkanen 2004) ja Helsingin yliopistossa koottiin jo 1940- ja 1950-luvuilla vaikuttajayksilöiden haastattelukokoelma. Sen sijaan Ruotsissa etenkin etnologit ovat tutkineet akateemista kulttuuria ja yliopistoja työpaikkana (esim. Ehn 2001; Gerholm \& Gerholm 1992). Anni Peura (2008) on hyödyntänyt kirjallista muistitietoa pari vuotta sitten ilmestyneessä väitöstutkimuksessaan, jossa on perehdytty tohtoroitumiseen ja siihen liittyviin perinteisiin Helsingin yliopistossa tohtoriksi väitelleiden näkökulmasta.

Tutkimuksessani eriaikaiset ja lähtökohdiltaan erilaiset hankkeet peilautuvat suhteessa toisiinsa. Hankkeet kuvaavat suomalaisen muistitietotutkimuksen monipuolista ja laajaa kenttää mutta osaltaan myös muistitietotutkimuksen kehittymistä viimeisten kahdenkymmenen vuoden aikana. Tällä kentällä toimivat sekä ammattitutkijat että yhteisön ja ryhmän historiasta ja perinteestä kiinnostuneet harrastajat, kuten paikallisjulkaisujen tekijät. Olenkin pitänyt tärkeänä sitä, että tutkimani hankkeet ovat lähteneet liikkeelle yhteisön sisältä, niiden halusta tutkia ja tuottaa omaa historiaansa.

\section{TUtKIJAN ROOLI MUISTITIETOHANKKEISSA}

Olen katsonut kohteitani eli kolmea muistitietohanketta tutkijana, mutta myös entisenä tai nykyisenä paikkakuntalaisena ja yhteisön jäsenenä. Toisin kuin klassisessa antropologisessa kenttätyössä, jota määrittää pitkäkestoinen oleskelu yleensä maantieteellisesti ja kulttuurisesti kaukaisella kentällä, olen entisellä kotipaikkakunnallani Enossa, nykyisessä kotikunnassani Kontiolahdessa ja opiskelu- ja työpaikassani Joensuun yliopistossa toiminut itselleni tutuilla ja läheisillä kentillä.

Enolaistaustasta oli hyötyä Kaltimoa koskevien haastattelujen tekemisessä. Paikallisten ihmisten tunteminen on muun muassa helpottanut kontaktien solmimista, minun onkin ollut helppo lähestyä mahdollisia haastateltavia. Puhe- ja ajattelutavan tuttuus vastaavasti on helpottanut kommunikaatiota ja molemminpuolista ymmärtämistä haastattelutilanteissa. Toimin haastatteluissa ensisijaisesti Kaltimon pahvitehtaasta kiinnostuneena akateemisena tutkijana enkä niinkään entisenä enolaisena. Nauhoja kuunnellessani huomasin käyttäneeni välillä paikallisille ihmisille vieraita, lähinnä tutkimuksista omaksuttuja ilmaisuja, mutta myös nykyajalle tyypillisiä käsitteitä. Paikallisten ilmaisujen ja murteen käyttö olisi luultavasti joissakin tilanteissa ollut järkevämpää eikä olisi aiheuttanut tarpeettomia väärinymmärryksiä. Jouduinkin välillä selventämään, mitä kysymykseni tai kommenttini tarkoitti, koska olin käyttänyt sellaista käsitettä tai lauserakennetta, jota kertoja ei ymmärtänyt. Kielenkäytölläni olen tiedostamattani etäännyttänyt itseäni enolaisuudesta ja samalla tuottanut eroa itseni ja kertojien välille.

Tutkijan ja yhteisön jäsenen roolit tulevat kiinnostavasti esille sekä yliopiston muistitietoprojektin että Kontiolahden kyläkirjahankkeen kohdalla. Tutkin kyläkirjahankkeessa omaa kotiseutuani ja pyrin - muiden hankkeen ohjaajien tavoin - toimimaan perinnepiirissä pikemminkin tasavertaisena osallisena kuin työtä ohjaavana auktori- 


\section{Elina Makkonen: Tutkijan rooli muistitietoetnografiassa}

teettina. Olin itse mukana aktiivisesti Pyytivaaran perinnepiirissä, jossa minulla kyllä oli asiantuntijan rooli ja muun muassa johdattelin keskustelua tarinailloissa. Kuitenkin keskustelumme oli yleensä leppoisaa ja tuttavallista, ja kahvittelu kuului illan ohjelmaan. Kaiken kaikkiaan työskentelyä kyläläisten kanssa leimasi tasavertaisuus. Koin olevani ennen kaikkea perinnepiirin jäsen enkä niinkään sen ohjaaja.

Yliopiston muistitietoprojektissakin tutkin omaa yhteisöäni, mutta koin olevani ennen kaikkea tutkijan roolissa. Roolini oli varsin selvä ja selkeä, sillä minut oli palkattu haastattelemaan yliopistolaisia ja myöhemmin kirjoittamaan julkaisu kootun aineiston pohjalta. Myös yliopistoyhteisön jäsenille tutkijan roolini tuntui olevan selvä eikä esimerkiksi haastattelutilanteissa rooliani yliopiston muistitietoa keräävänä haastattelijana kyseenalaistettu. Olin varsin monissa haastatteluissa kertojaa alempana yliopistohierarkiassa, mutta pääsääntöisesti minuun suhtauduttiin hyvin ja projektistamme oltiin kiinnostuneita.

Olen haastattelutilanteissa sekä julkaisuja ja tutkimusta kirjoittaessani pohtinut positiotani sekä joutunut miettimään sisä- ja ulkoryhmäläisyyteen liittyviä kysymyksiä. Päivikki Suojasen mukaan oman ja itselle läheisen kulttuuri-ilmiön tutkimisessa onkin tärkeää kyetä etäännyttämään itsensä. Tutkijan on siis osallisuudestaan ja sisäpiiriläisyydestään huolimatta otettava ainakin hetkellisesti ulkopuolisen positio ja katsottava kohdettaan kauempaa. (Suojanen 1996.) Myöskään muistitietotutkija Alessandro Portellin $(1997,269)$ mukaan ei voida puhua sisäpiirissä olevasta tutkijasta ("inside" researcher), koska tutkijan rooliin siirtyessään sisäpiiriläisestä tulee ulkopuolinen.

Väitöstutkimukseni on pitkän ja monivaiheisen prosessin tulos. Lähes kahdenkymmenen vuoden aikana mukaan on tullut runsaasti uusia lähestymistapoja, puhumattakaan siitä, että olen laajentanut tarkasteluani yhdestä hankkeesta kolmeen muistitietohankkeeseen. Tutkimuksessani tuleekin näkyväksi etnografisen ja muistitietotutkimuksen prosessimaisuuden lisäksi omien näkemysteni muuttuminen ja syventyminen uusien hankkeiden ja näkökulmien sekä muistitietotutkimuksen yleisemmän kehittymisen myötä.

Hankkeiden vertaileva asetelma mahdollistaa muisteluaineistojen, muistitietohankkeiden ja -julkaisujen tarkastelun osana omaa tutkimusprosessiani. Käyttämäni muistitietoetnografian ote, jossa tutkija nähdään merkittävänä toimijana, on yhtenä perusteluna sille, että kolmea näinkin erilaista hanketta voidaan tarkastella rinnakkain. Tutkija on siis yksi tutkimuskohteita yhdistävä tekijä ja nimenomaan hän tuottaa muistitiedosta etnografiaa.

\section{EETTISIÄ KYSYMYKSIÄ}

Viimeisten vuosikymmenten aikana ihmistieteiden piirissä on kiinnitetty erityistä huomiota tutkijan rooliin yhtenä tutkimukseen osallistuvana toimijana, neuvottelijana ja tutkimustiedon tuottajana. Olen haastattelutilanteissa, julkaisuja laatiessani ja tutkimusta kirjoittaessani vaikuttanut muistitiedon muodostumiseen ja menneisyyden esitysten rakentumiseen. Onkin aiheellista pohtia, myös tutkimuseettisestä näkökulmasta, kenen ääni tutkimuksessani kuuluu. Annanko tutkimuksessani riittävästi tilaa kaltimolaisten, kontiolahtelaisten ja yliopistolaisten muistoille ja äänille? 


\section{Elina Makkonen: Tutkijan rooli muistitietoetnografiassa}

Johanna Uotinen on todennut, että tutkittavien oman äänen esille tuomiseen ja heidän subjektiviteettinsa tunnustamiseen pyrkivä tutkimustapa on tavoiteltava, muttei se suinkaan ole ongelmaton. Hän kysyy oivaltavasti, miten laadullista tutkimusta määrittävä ajatus äänten kunnioittamisesta sopii ajatukseen tiedon subjektiivisuudesta, kontekstisidonnaisuudesta ja välittyneisyydestä. Onkin ristiriitaista, että tutkimuksen tavoitteena on välittää tutkittavan koskematon ääni, mutta samalla tutkimusta pidetään tutkittavien ja tutkijan yhteistyön tuloksena. (Uotinen 2008, 134.)

Eettisesti pätevän tutkimuksen vaade laittaa muistitietoetnografin pohtimaan tutkimuksen tasavertaisuutta ja symmetrisyyttä. Mielestäni tutkimus ei voi olla täysin tasavertaista, koska tutkija ja tutkittava eivät ole tutkimusprosessissa yhdenveroisessa asemassa. Esimerkiksi Kaltimon tehdaslapsuutta koskevassa tutkimuksessa symmetria edellyttäisi sitä, että kertojat olisivat jo haastattelutilanteessa minun kanssani tasavertaisia keskustelijoita ja he olisivat voineet myös osallistua tutkimuksen kirjoittamiseen. (Vrt. Vasenkari 1996b, 28-29.) Olen kyllä luetuttanut tutkimustekstejäni entisillä kaltimolaisilla, mutta tosiasiassa minulla on ollut valta päättää monista tutkimuksen yksityiskohdista. Olen muun muassa valinnut haastateltavat, johtanut keskustelua haastattelutilanteessa, muodostanut tutkimuksessa käytettävän aineiston ja muotoillut tutkimuskysymykset sekä valikoinut kenen tai keiden kerrontaan teksteissäni viittaan. Olenkin sitä mieltä, että vaikka tutkija kuinka pyrkisi tekemään dialogista tutkimusta, on tutkimus viime kädessä tutkijavetoista. (Ks. esim. Crapanzano 1990, 271-272, 287; Fingerroos \& Haanpää 2006, 36-40; Portelli 1991, 54, 56; Vasenkari 1996a, 88.)

Vaikka symmetristä tutkimusta on mahdotonta tehdä, on tutkijan oltava tietoinen epäsymmetriasta. Hän voi, Maria Vasenkaria lainaten, pitää epäsymmetrisyyttä aisoissa tekemällä eettisesti harkittuja ratkaisuja. (Vasenkari 1996b, 29.) Eettisesti oikein toimivan tutkijan on mietittävä omia positioitaan, pohdittava tutkimuksellisia lähtökohtiaan ja kaiken kaikkiaan pyrittävä tuomaan realistisesti ja mahdollisimman selkeästi esille oma roolinsa yhtenä tutkimuksen osapuolena ja tutkimuksessa tuotettavien tulkintojen ja merkitysten tuottajana. Teemu Taira on todennut, että vaikka tutkijan ääni onkin tutkimuksessa hallitseva, niin tutkijan lähestymistavan selvittäminen luo parhaimman mahdollisuuden tasavertaisuuteen tutkijan, tutkimuskohteen ja yleisön välille. Tutkija osoittaa, ettei hän sano aineistosta totaalista totuutta, vaan sen, mitä hän välineitään eli valittuja teoreettisia käsitteitä ja jäsennyksiä käyttäen pystyy aiheesta sanomaan. (Taira 2004, 47.)

Oman positionsa tiedostavan muistitietotutkijan ja -etnografin olisikin mietittävä, miksi on tutkimuksessa päätynyt tiettyihin ratkaisuihin ja mitkä seikat valintoja ohjaavat. Esimerkiksi omassa tutkimuksessani olen pyrkinyt tuomaan esille sen, mitä valintoja olen kulloinkin tehnyt, miksi olen päätynyt tiettyihin ratkaisuihin ja mikä on ohjannut tutkijan katsettani tutkimusta tehdessäni. Olen halunnut painottaa, että tutkimuksessa kyse on nimenomaan omista tulkinnoistani, joiden taustalla kyllä ovat kaltimolaisten, kontiolahtelaisten ja Joensuun yliopistolaisten kuvaukset, kertomukset, menneisyyden tulkinnat ja painotukset. Ymmärtävään muistitietotutkimukseen ankkuroituvassa muistitietoetnografiassa tutkijan rooli kuitenkin saa ja sen pitääkin olla näkyvissä. 
Elina Makkonen: Tutkijan rooli muistitietoetnografiassa

\section{KirJallisuUs}

CRAPANZANO, VINCENT 1990: On Dialogue. - Maranhão, Tullio (ed.), The Interpretation of Dialogue. Chicago: The University of Chicago Press.

EHN, BILLY 2001: Universitetet som arbetsplats. Reflektioner kring ledarskap och kollegial professionalism. Etnologiska skrifter nr 26. Lund: Studentlitteratur.

FINGERROOS, OUTI 2003: Refleksiivinen paikantaminen kulttuurien tutkimuksessa. - Elore 10(2) [online]. < http://www.elore.fi/arkisto/2_03/fin203c.html > [Viitattu 29.1.2009.]

FINGERROOS, OUTI \& HAANPÄÄ, RIINA 2006: Muistitietotutkimuksen ydinkysymyksiä. - Fingerroos, Outi \& Haanpää, Riina \& Heimo, Anne \& Peltonen, Ulla-Maija (toim.), Muistitietotutkimus. Metodologisia kysymyksiä. Tietolipas 214. Helsinki: Suomalaisen Kirjallisuuden Seura.

GERHOLM, LENA \& GERHOLM, TOMAS 1992: Doktorshatten. En studie av forskarutbildningen inom sex discipliner vid Stockholms universitet. Stockholm: Carlssons.

HAANPÄÄ, RIINA 2008: Rikosten jäljet. Etsivän työtä ybteisön, suvun ja perheen muistissa. Turun yliopiston julkaisuja. Sarja C Scripta lingua Fennica edita, osa 270. Turku: Turun yliopisto.

HOSIAISLUOMA, YRJÖ 2000: Hanat auki! Tampereen yliopiston virallinen kaskukirja. Tampere: Tampere University Press.

LAPPALAINEN, SIRPA 2007: Johdanto. Mikä ihmeen etnografia? - Lappalainen, Sirpa \& Hynninen, Pirkko \& Kankkunen, Tarja \& Lahelma, Elina \& Tolonen, Tarja (toim.) 2007: Etnografia metodologiana. Lähtökobtana koulutuksen tutkimus. Tampere: Vastapaino.

MAKKONEN, ELINA 1993: Tehtaalaislapsuns muistoissa. Muistitiedon antama kuva elämästä Kaltimon pahvitehtaalla 1910 - 1940 -luvilla. Julkaisematon perinteentutkimuksen pro gradu -tutkielma. Joensuun yliopiston suomen kielen ja kulttuuritieteiden laitos.

- 1997: Tehtaalaislapsuns Kaltimossa - muistoja pabvitehtaalta. Eno: Eno-Seura.

- 2000a: Elinikäinen lapsuns. Muistikuvia Kaltimon tebdasybteisöstä. Julkaisematon perinteentutkimuksen lisensiaatintutkielma. Joensuun yliopiston suomen kielen ja kulttuuritieteiden laitos.

- 2000b: Miserable or golden childhood? Narrated memories of an industrial community. - Vasenkari, Maria \& Enges, Pasi \& Siikala, Anna-Leena (eds.), Telling, Remembering, Interpreting, Guessing. A Festschrift for prof. Annikki Kaivola-Bregenhøj on her 60th Birthday 1st February 1999. Kultaneito III. Joensuu: Suomen Kansantietouden Tutkijain Seura \& Scripta Aboensia 1, Studies in Folkloristics.

- 2004a: Muistin mukaan. Joensunn yliopiston suullinen historia. Joensuu: Joensuun yliopisto.

- 2004b: From Present to Past: Discources of Remembered Chidlhoods. - Brembeck, Helene \& Johansson, Barbro \& Kampmann, Jan (eds.), Beyond the Competent Child. Exploring Contemporary Childhoods in the Nordic Welfare Societies. Fredriksberg: Roskilde Universitetsforlag.

MAKKONEN, ELINA \& PEKKINEN, SANNA \& RANINEN-SIISKONEN, TARJA 1999: Kyläkirjaopas. Kultaneito II. Joensuu: Suomen Kansantietouden Tutkijain Seura \& Kontiolahden kylien kehittämiskeskusosuuskunta. 
OJANEN, KAROLIINA 2008: Kenttäkokemuksesta tiedoksi. - Elore 15(1) [online] $<$ http://www.elore.fi/arkisto/1_08/oja1_08.pdf > [Viitattu 29.1.2010.]

PEURA, ANNI 2008: Tobtoriksi tulemisen tarina. Kasvatustieteen laitoksen tutkimuksia 219. Helsinki: Helsingin yliopisto.

PORTELLI, ALESSANDRO 1991: The Death of Luigi Trastulli and Other Stories. Form and Meaning in Oral History. Albany (New York): State University of New York Press.

-1997: The Battle of Valle Giulia. Oral History and the Art of Dialogue. Madison (Wis.): University of Wisconsin Press.

SOIKKANEN, TIMO 2004: Akateemini buumori Auran rannoin 1200-luvult 2000-luvul. Turku: Kaskuakatemia.

SUOJANEN, PÄIVIKKI 1996: Kulttuurien tutkijan arki. Kokemuksia omasta ja vieraasta. Jyväskylä: Antrokirjat.

TAIRA, TEEMU 2004: Kartanpiirtäjän kulkuneuvo. Kirjoituskilpakeruun lukumahdollisuuksista. - Kurki, Tuulikki (toim.), Kansanrunousarkisto. Lukijat ja tulkinnat. Suomalaisen Kirjallisuuden Seuran Toimituksia 1002. Helsinki: Suomalaisen Kirjallisuuden Seura.

UKKONEN, TAINA 2006: Yhteistyö, vuorovaikutus ja narratiivisuus muistitietotutkimuksessa. - Fingerroos, Outi \& Haanpää, Riina \& Heimo, Anne \& Peltonen, Ulla-Maija (toim.), Muistitietotutkimus. Metodologisia kysymyksiä. Tietolipas 214. Helsinki: Suomalaisen Kirjallisuuden Seura.

UOTINEN, JOHANNA 2008: Juoksuhiekka ja tilkkutäkki - laadulliset tutkimuskäytännöt ja äänen kunnioittaminen. - Fingerroos, Outi \& Kurki, Tuulikki (toim.), Ä̈niä arkistosta. Haastattelut ja tulkinta. Suomalaisen Kirjallisuuden Seuran Toimituksia 1194. Helsinki: Suomalaisen Kirjallisuuden Seura.

VASENKARI, MARIA 1996a: Mitä se sanoo? Mistä se kertoo? Dialoginen näkökulma kenttätutkimusaineiston tuottamiseen. - Hovi, Tuija \& Tarkka, Lotte (toim.), Uskontotiede - folkloristiikka. Kirjoituksia opinnäytteistä. Etiäinen 3. Turku: Turun yliopisto, kulttuurien tutkimuksen laitos.

-1996b: Osallistuvan havainnoinnin menetelmä kulttuurin kenttätutkimuksessa. Vasenkari, Maria (toim.), Kulttuurin kenttätutkimukesen alkeet: osallistuva havainnointi. Turku: Turun yliopiston täydennyskoulutuskeskus.

Makkonen, Elina 2009: Muistitiedon etnografiaa tuottamassa. Joensuun yliopiston bumanistisia julkaisuja 58. Joensun: Joensumn yliopisto.

Filosofian lisensiaatti (väit.) Elina Makkonen on kontiolahtelainen perinteentutkija. 